\title{
Suplemen Jus Daun Afrika (Vernonia amygdalina) dalam Air Minum terhadap Komposisi Kimia dan Kadar Malondialdehid Telur Puyuh (Coturnix coturnix japonica)
}

\author{
African Leaf (Vernonia amygdalina) Juice Supplement in Drinking Water on the Chemical Properties of Quail Egg (Coturnix \\ coturnix japonica)
}

\section{Hasbullah', Z Wulandari², D M Suci*}

Corresponding email:

dwi.margi@gmail.com

1 Departemen Ilmu Nutrisi dan Teknologi Pakan, Fakultas Peternakan, Institut Pertanian Bogor (Bogor Agricultural University/IPB University)

2 Departemen Ilmu Produksi dan Teknologi Peternakan, Fakultas Peternakan, Institut Pertanian Bogor (Bogor Agricultural University/IPB University)

\section{ABSTRACT}

This study aimed to determine the effectiveness of African leaf juice supplements on the chemical properties of quail eggs. This research used 120 quails aged 8 weeks, which divided into 3 treatments and 5 replications. The experimental design used a completely randomized and the treatments were P0 : without the supplementation of African leaf juice as controls, P1: addition of $3 \mathrm{ml} \mathrm{head}^{-1}$ day-1 $^{-1}$ African leaf juice, and P2: addition of $6 \mathrm{ml} \mathrm{head}^{-1}$ day $^{-1}$ African leaf juice (P2). The variables observed were moisture, ash, crude protein, ether extract, carbohydrate, malondialdehyde content (MDA), pH and water activity (Aw) in yolk and albumen. The results showed that moisture, ash, crude protein, ether extract, and carbohydrate content in egg yolks had no different effect compared to controls. Malondialdehid (MDA) content in the treatment of $3 \mathrm{ml} \mathrm{head}^{-1}$ day $^{-1}$ and $6 \mathrm{ml} \mathrm{head}^{-1}$ day $^{-1}$ of African leaf juice supplementation decreased $39.68 \%$ and $36.19 \%$ compared to control. Aw level in yolk and albumen significantly $(\mathrm{p}<0.05)$ decreased in $6 \mathrm{ml}$ of African leaf juice supplementation, but no effect on the $\mathrm{pH}$ eggyolk and albumen. It was concluded that addition of $3 \mathrm{ml}$ and $6 \mathrm{ml}$ of African leaf juice head ${ }^{-1}$ day $^{-1}$ could reduce the MDA content of egg yolk.

Key words: egg nutrient composition, malondialdehyde, quail, Vernonia amygdalina

\section{ABSTRAK}

Penelitian ini bertujuan mengetahui efektivitas suplemen daun afrika pada puyuh terhadap kualitas kimia telur puyuh. Penelitian ini menggunakan 120 ekor puyuh umur 8 minggu yang dibagi menjadi 3 perlakuan dan 5 ulangan. Rancangan yang digunakan adalah rancangan acak lengkap dengan perlakuan yaitu tanpa jus daun afrika sebagai kontrol (P0), 3 ml ekor $^{-1}$ hari $^{-1}$ jus daun afrika (P1) dan $6 \mathrm{ml} \mathrm{ekor}^{-1}$ hari $^{-1}$ jus daun afrika (P2). Pengambilan sampel telur dilakukan pada minggu ke enam perlakuan. Variabel yang diamati yaitu kadar air, kadar abu, kadar protein kasar, kadar lemak kasar, kadar karbohidrat, kadar malondialdehid (MDA), serta pH dan Aw kuning dan putih telur. Hasil penelitian menunjukkan kadar air, kadar abu, kadar protein kasar, kadar lemak kasar dan karbohidrat kuning telur tidak berbeda nyata dibandingkan dengan kontrol. Kadar MDA pada perlakuan $3 \mathrm{ml}_{\text {ekor-1 }}$ hari $^{-1}$ dan $6 \mathrm{ml}^{\text {ekor }}{ }^{-1}$ hari ${ }^{-1}$ menurun sebesar $39,68 \%$ dan 36,19\% dibandingkan dengan kontrol. Nilai Aw kuning dan putih telur nyata $(\mathrm{p}<0.05)$ menurun pada perlakuan $6 \mathrm{ml}^{\text {ekor-1 }}$ hari $^{-1}$, namun tidak terdapat perbedaan pada $\mathrm{pH}$ kuning dan putih telur. Kesimpulan dari hasil penelitian bahwa suplementasi jus daun afrika sebesar $3 \mathrm{ml}$ dan $6 \mathrm{ml}^{\text {ekor-1 }}$ hari-1 $^{-1}$ mampu menurunkan kadar MDA kuning telur.

Kata kunci: komposisi kimia telur, malondialdehid, puyuh, Vernonia amygdalina 


\section{PENDAHULUAN}

Antioksidan memiliki peran penting dalam mengurangi stres oksidatif dan dapat mengurangi kerusakan yang ditimbulkan oleh radikal bebas. Antioksidan bekerja dengan cara menghentikan pembentukan radikal bebas, menetralisir serta memperbaiki kerusakan-kerusakan yang terjadi (Dillasamola \& Linda 2016). Sumber antioksidan alami dapat ditemukan pada tanamantanaman herbal yang salah satunya adalah daun afrika.

Tumbuhan Afrika (Vernonia amygdalina Del.) di Indonesia dikenal dengan nama daun afrika. Penelitian menggunakan daun afrika pada mencit mampu menurunkan kadar MDA pada hati, paru-paru, jantung dan darah. Kandungan antioksidan pada daun afrika memiliki kapasitas yang tinggi memasuki plasma darah dan organ (Ho et al. 2012). Ho et al. (2012) juga menyatakan bahwa kandungan flavonoid pada daun afrika merupakan sumber antioksidan yang lebih baik dibandingkan dengan vitamin C. Menurut Atangwho et al. (2013), daun afrika diketahui memiliki level antioksidan yang tinggi karena memiliki kandungan luteolin yang merupakan senyawa aktif dari golongan flavonoid.

Senyawa kimia yang terkandung dalam daun Afrika antara lain flavonoid $11,50 \pm 1,01 \%$, saponin $2,50 \pm$ $0,41 \%$, alkaloid $1,03 \pm 0,04 \%$, beta-caroten $9,05 \pm 2,10$

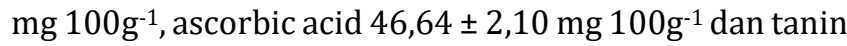
$0,17 \pm 0,04 \%$ (Usunobun \& Okolie 2015). Flavanoid pada daun afrika berpotensi sebagai antioksidan yang memiliki nilai IC50 87,992 ppm (Sukmawati et al. 2017). Hal ini menunjukkan bahwa daun afrika dapat berpotensi untuk mengatasi stress oksidatif dan mampu menurunkan kadar MDA pada telur puyuh, karena antioksidan memiliki peran penting dalam mengurangi stres oksidatif dan dapat mengurangi kerusakan yang ditimbulkan oleh radikal bebas (Nurfianti \& Tribudi 2016). MDA merupakan produk akhir hasil peroksidasi lemak yang digunakan sebagai biomarker biologis peroksidasasi lemak serta menggambarkan derajat stres oksidatif. Tingginya kadar MDA mengindikasikan terjadinya stres oksidatif yang tinggi (Maheswari et al. 2017).

Pengaruh cekaman panas yang dialami puyuh akan dapat diperbaiki oleh suplemen jus daun afrika yang diberikan melalui air minum dengan adanya senyawa aktif yang dapat berperan sebagai antioksidan. Oleh karena itu, penelitian ini dilakukan bertujuan mengetahui efektivitas pemberian daun afrika dalam menanggulangi kondisi stres oksidatif pada burung puyuh dan pengaruhnya terhadap komposisi kimia telur yang dihasilkan.
Tabel 1 Kandungan nutrien pakan

\begin{tabular}{lc}
\hline Kandungan nutrien (\%) & Hasil analisis \\
\hline Kadar air & 8,00 \\
Protein kasar & 22,80 \\
Lemak kasar & 5,69 \\
Serat kasar & 2,97 \\
Abu & 12,47 \\
Kalsium & - \\
\hline Laboratorium PAU IPB (2020)
\end{tabular}

\section{METODE}

\section{Ternak dan Kandang}

Ternak yang digunakan pada penelitian adalah puyuh petelur Coturnix coturnix japonica yang berumur 8 minggu sebanyak 120 ekor yang ditempatkan pada kandang koloni dengan 3 perlakuan dan 5 ulangan dengan masing-masing ulangan terdiri dari 8 ekor puyuh. Puyuh dipelihara selama 6 minggu. Kandang yang digunakan adalah kandang koloni bertingkat dengan ukuran panjang $60 \mathrm{~cm}$, lebar $50 \mathrm{~cm}$, dan tinggi $25 \mathrm{~cm}$. Setiap kandang dilengkapi tempat pakan dan air minum.

\section{Ransum dan Jus Daun Afrika}

Ransum yang digunakan merupakan ransum komersial puyuh petelur periode layer (Tabel 1) mengandung protein 22,8\%. Ransum diberikan sesuai dengan kebutuhan puyuh yaitu 25 g ekor $^{-1}$ hari $^{-1}$. Jus Afrika diberikan melalui air minum dengan jumlah total air minum sesuai dengan kebutuhan puyuh yaitu $65 \mathrm{ml}$ ekor${ }^{1}$ hari $^{-1}$. Air minum perlakuan diberikan pada pagi hari, kemudian siang hari diganti dengan air minum tanpa jus yang baru.

Daun afrika yang berada 3-5 helai dari pucuk digunakan dalam penelitian ini. Daun afrika ditimbang sebanyak $100 \mathrm{~g}$ kemudian direndam dalam air selama 24 jam. Pembuatan jus daun afrika dilakukan dengan menambahkan $200 \mathrm{ml}$ air dalam $100 \mathrm{~g}$ daun afrika dengan perbandingan 2:1 yang dihaluskan menggunakan blender. Daun afrika yang sudah halus disaring dan ditampung dalam wadah (modifikasi dari Halimah et al. 2019). Komposisi senyawa aktif (fitokimia) jus daun afrika tertera pada Tabel 2.

Tabel 2 Hasil analisis fitokimia jus daun afrika

\begin{tabular}{lc}
\hline Jenis Fitokimia & Jus daun afrika \\
\hline Alkaloid & + \\
Flavonoid & ++ \\
Phenolhidroquinon & + \\
Steroid & + \\
Triterpenoid & - \\
Tanin & ++ \\
Saponin & +++ \\
\hline$-=$ tidak ada, + = sedikit, ++ = sedang, +++ = banyak ; Laboratorium \\
Kimia Analitik, Fakultas Matematika dan Ilmu Pengetahuan Alam, \\
IPB University (2020)
\end{tabular}




\section{Rancangan Percobaan dan Analisis Data}

Perlakuan yang digunakan untuk setiap satuan percobaan (per ekor per hari) dalam penelitian ini adalah P0 : air minum tanpa jus daun afrika ( $65 \mathrm{ml}$ air bersih), $\mathrm{P} 1$ : air minum dengan $3 \mathrm{ml}$ jus daun afrika $+62 \mathrm{ml}$ air bersih dan P2 : air minum dengan $6 \mathrm{ml}$ jus daun afrika + $59 \mathrm{ml}$ air bersih.

Rancangan percobaan yang digunakan untuk pemeliharaan yaitu rancangan acak lengkap dengan 3 perlakuan dan 5 ulangan. Masing-masing ulangan diisi sebanyak 8 ekor burung puyuh. Data hasil analisis proksimat, MDA, pH dan Aw diolah dengan Analysis of Variance menggunakan SPSS 25dan jika diperoleh hasil berbeda nyata dilakukan uji kontras orthogonal.

\section{Peubah yang Diamati \\ Pengambilan sampel telur}

Sampel telur yang digunakan sebanyak satu sampel per ulangan dari beberapa butir telur (10-15 butir telur) untuk pengujian proksimat, MDA, $\mathrm{pH}$, Aw. Pengujian $\mathrm{pH}$ dan AW dilakukan pada bagian kuning dan putih telur. Telur puyuh yang digunakan sebagai sampel diambil pada minggu ke-6 sejak awal pemberian perlakuan. Bagian telur puyuh yang digunakan untuk analisis MDA dan proksimat adalah kuning telur.

\section{Komposisi kimia kuning telur (analisis proksimat)}

Analisis kadar protein kasar, kadar lemak kasar, kadar abu, dan kadar air kuning telur dilakukan berdasarkan metode pada AOAC (1980). Analisis kadar karbohidrat dilakukan berdasarkan perhitungan karbohidrat by difference (Ferazuma et al. 2011). Kadar karbohidrat dapat dihitung dengan menggunakan rumus:

$\%$ Karbohidrat $=100 \%-(\% \mathrm{Abu}+\% \mathrm{Air}+\%$ Lemak $+\%$ Protein $)$

\section{Kadar Malondialdehida (MDA) kuning telur puyuh}

Pengukuran kadar MDA dilakukan berdasarkan metode pada Diplock et al. (1991). Kuning telur puyuh sebanyak $\pm 1,25 \mathrm{~g}$ ditambahkan dengan $5 \mathrm{ml}$ larutan PBS dihomogenkan kemudian di sentrifuse dengan kecepatan $4000 \mathrm{rpm}$ selama 20 menit. Hasil sentrifuse berupa supernatan diambil sebanyak $0,5 \mathrm{ml}$ untuk analisis MDA. Supernatan sebanyak $0,5 \mathrm{ml}+2 \mathrm{ml}$ larutan campuran yang terdiri dari Trichloroacetic Acid (TCA), Thiobarbituric Acid (TBA), dan Hydrochloric Acid (HCl), kemudian dihomogenkan dan dimasukkan ke dalam waterbath dengan suhu $80^{\circ} \mathrm{C}$ selama 1 jam. Setelah itu, supernatan didinginkan dengan air mengalir kemudian di sentrifuse kembali dengan kecepatan 3500 rpm selama 10 menit. Setelah didapatkan supernatan, dimasukkan ke dalam spektrofotometer uv-visible dengan panjang gelombang $532 \mathrm{~nm}$ untuk mengukur absorbansinya. Nilai absorbansi sampel disubtitusi ke dalam persamaan pada kurva standar TEP (tetraetoksipropana): $\mathrm{Y}=\mathrm{aX}+\mathrm{b}$. Konsentrasi MDA dihitung berdasarkan rumus :

$$
\text { Kadar MDA }=\frac{(\text { Absorbansi }-\mathrm{b}) / \mathrm{a}}{\text { Volume sampel }} \mathrm{xFp}
$$

Keterangan:

Fp : Faktor pengenceran

a,b : koefisien pada persamaan regresi kurva TEP $(\mathrm{Y}=\mathrm{aX}+\mathrm{b})$

\section{Kemasaman telur puyuh}

Pengukuran $\mathrm{pH}$ dilakukan menggunakan $\mathrm{pH}$ meter merk schott seri Lab 850 yang sebelumnya dikalibrasi pada $\mathrm{pH}$ 4 dan 7.

\section{Water Activity (Aw) pada telur puyuh}

Penentuan nilai aktivitas air dari produk diukur dengan menggunakan alat pengukur AW meter merk novasina ms1. Pengukuran nilai aw dilakukan dengan cara memasukkan sampel yang akan diukur dalam wadah yang tersedia pada alat tersebut, kemudian sampel didiamkan kurang lebih lima menit, setelah itu dilihat nilai aw yang tertera pada alat tersebut.

\section{HASIL DAN PEMBAHASAN}

\section{Komposisi Kimia Kuning Telur Puyuh Kadar Air Kuning Telur}

Pada penelitian ini diketahui bahwa pemberian jus daun afrika tidak mempengaruhi kadar air pada kuning telur puyuh. Kadar air kuning telur pada penelitian ini (Tabel 3) menunjukkan hasil yang lebih rendah dibandingkan dengan hasil Dudusola (2010) yaitu 49,71\% dan Prelipcean \& Teusan (2012) sebesar 49,79\%. Perbedaan kualitas telur tersebut dapat disebabkan oleh kondisi lingkungan yang berbeda (Nowaczewski et al. 2010).

\section{Kadar Abu Kuning Telur}

Efek antioksidan pada jus daun afrika dalam penelitian ini tidak memberikan pengaruh terhadap kadar abu pada kuning telur (Tabel 3). Pada penelitian ini menggunakan ransum komersial yang sudah mencukupi kebutuhan $\mathrm{Ca}$ dan $P$ untuk puyuh petelur. Pengaruh dari senyawa flavonoid pada jus daun afrika tidak mempengaruhi kadar abu kuning telur. Walaupun menurut Tugiyanti et al (2017) flavonoid, quercetin, tannin, saponin, steroid, glikosida yang terdapat dalam daun sukun merupakan salah satu golongan flavonoid yaitu fraksi etil asetat yang merupakan senyawa aktif yang mampu mengikat kalsium akan membentuk suatu ikatan kalsium flavonoid membentuk senyawa kompleks dengan gugus $\mathrm{OH}$ dari flavonoid sehingga membentuk Ca-flavonoid. Caflavonoid ini diduga memiliki peran dalam menebalkan kerabang telur. Selain itu menurut Fouad et al. (2016)

Tabel 3 Komposisi kimia kuning telur puyuh

\begin{tabular}{lrrr}
\hline Parameter & P0 & P1 & P2 \\
\hline Kadar air (\%) & $48,71 \pm 0,26$ & $48,66 \pm 0,53$ & $48,44 \pm 0,25$ \\
Kadar abu (\%) & $1,82 \pm 0,04$ & $1,79 \pm 0,03$ & $1,82 \pm 0,14$ \\
Kadar protein kasar (\%) & $14,72 \pm 0,41$ & $14,31 \pm 0,22$ & $14,42 \pm 0,31$ \\
Kadar lemak kasar (\%) & $28,33 \pm 0,12$ & $27,26 \pm 0,46$ & $27,81 \pm 1,12$ \\
Kadar karbohidrat (\%) & $6,43 \pm 0,46$ & $7,99 \pm 0,86$ & $7,52 \pm 1,24$ \\
\hline Hasil analisis proksimat di Laboratorium PAU IPB; P0 (kontrol), P1(3 \\
ml jus daun afrika ekor-1 hari-1), P2(6 ml jus daun afrika ekor-1 hari-1). $^{-1}$.
\end{tabular}


Produksi radikal bebas yang tinggi akibat cekaman panas akan menekan penyerapan kalsium dan fospor (Fouad et al. 2016), sehingga stres akibat cekaman panas dapat menurunkan ketebalan kerabang telur. Hasil penelitian ini sesuai dengan Dudusola (2010) bahwa kadar abu kuning telur adalah $1,79 \%$ dan menurut Tolik et al. (2014) adalah 1,8\%, tetapi lebih rendah dari Prelipcean \& Teusan (2012) yaitu 2,16\%.

\section{Kadar Protein Kasar Kuning Telur}

Pemberian jus daun afrika melalui air minum pada penelitian ini tidak mempengaruhi kadar protein kasar kuning telur (Tabel 3). Pada pemberian jus daun afrika tidak terjadi hambatan penyerapan nutrien yang disebabkan oleh zat senyawa aktif ataupun anti nutrien terutama tannin yang terdapat pada daun afrika. Oboh (2006) menyatakan bahwa daun afrika mempunyai anti nutrien diantaranya adalah asam fitat, cyanida dan tannin. Anti nutrisi dalam konsentrasi yang tidak tepat dapat menghambat penyerapan nutrien pakan namun dalam dosis yang tepat dapat meningkatkan permeabilitas usus dan membantu penyerapan.Selain itu cekaman panas pada puyuh dapat menurunkan efisiensi penggunaan protein untuk memproduksi telur (Suprijatna et al. 2008). Senyawa aktif yang berperan sebagai antioksidan pada daun afrika untuk mencegah cekaman panas belum terlihat pada penelitian ini, karena kemungkinan puyuh belum mengalami cekaman panas yang berat sehingga efisiensi sintesis kuning telur tidak terganggu.. Rataan suhu dan kelembaban relatif harian lingkungan kandang yaitu $27,79{ }^{\circ} \mathrm{C}$ dan $81,75 \%$.

\section{Kadar Lemak Kasar Kuning Telur}

Kadar lemak kuning telur puyuh pada penelitian ini tidak memberikan perbedaan yang signifikan antara perlakuan jus daun afrika dengan kontrol. Hasil penelitian ini mendapatkan kadar lemak kasar kuning telur puyuh yang lebih rendah dibandingkan dengan hasil Dudusola (2010) yaitu 31,48\% dan Prelipcean \& Teusan (2012) sebesar 29,45\%, tetapi lebih tinggi dibandingkan dengan Sinanoglou et al. (2011) yaitu 27,45\%. Rukmiasih et al. 2009) menyatakan bahwa pemberian beluntas (Pluchea indica L. Less) yang mengandung antioksidan (flavonoid, vitamin $\mathrm{C}$ dan betakaroten) tidak mempengaruhi kadar lemak kuning telur itik lokal. Grigorova et al. (2014) menyatakan bahwa penambahan ekstrak Tribulus terrestris yang mengandung antioksidan ke dalam air minum terhadap puyuh berumur 10 minggu tidak memberikan perbedaan yang nyata pada kadar lemak kuning telur. Proses pembentukan telur dipengaruhi oleh nutrien yang dikonsumsi oleh unggas tersebut. Pemberian antioksidan akan menurunkan peroksidasi lipid dan meningkatkan kolesterol kuning telur. Antioksidan akan menuju kantung membran dan diubah menjadi lipoprotein yang mendukung proses pertumbuhan embrio (Faradillah et al. 2015).

\section{Kadar Karbohidrat Kuning Telur}

Kadar karbohidrat kuning telur puyuh pada penelitian ini tidak memberikan perbedaan yang signifikan antara perlakuan jus daun afrika dengan kontrol. Hal ini dapat disebabkan karena ternak diberikan jenis pakan yang sama dan kandungan nutrien yang sama, sehingga tidak memberikan perbedaan pada kadar karbohidrat kuning telur. Menurut Landung et al. (2013), cekaman panas dapat mempengaruhi kinerja dan perkembangan usus halus sehingga mempengaruhi efektivitas penyerapan nutrien. Zat antioksidan diketahui mampu mengatasi cekaman panas sehingga dapat memperbaiki proses penyerapan nutrien (Landung et al. 2013). Saluran pencernaan terutama usus halus, sebagai tempat berlangsungnya proses penyerapan nutrien dapat berkembang lebih baik apabila terhindar dari cekaman panas.

\section{Kadar Malondialdehid (MDA) pada Kuning Telur Puyuh}

Hasil penelitian menunjukkan bahwa pemberian jus daun afrika berpengaruh nyata $(p<0,05)$ terhadap penurunan kadar MDA dalam kuning telur puyuh. Tabel 4 menunjukkan nilai MDA pada kuning telur puyuh. Malondialdehid (MDA) merupakan produk akhir hasil peroksidasi lemak yang digunakan sebagai biomarker biologis peroksidasi lemak serta menggambarkan derajat stres oksidatif.

Pemberian jus daun afrika mampu menurunkan kadar MDA sebesar 39,68\% dari kontrol pada perlakuan P1 (3 ml ekor-1 hari $^{-1}$ ) dan menurunkan sebesar 36,19\% dari kontrol pada perlakuan P2 (6 ml ekor-1 hari-1). Hal ini mengindikasikan bahwa penggunaan jus daun afrika mampu menurunkan stres oksidatif. Kadar MDA kuning telur puyuh berdasarkan penelitian Nurfianti \& Tribudi (2016) yaitu $1,92 \pm 0,35 \mathrm{mg} \mathrm{kg}^{-1}$ dan $5,40 \pm 0,51 \mathrm{mg} \mathrm{kg}^{-1}$ berdasarkan Faradillah et al. (2015). Kadar MDA yang didapatkan penelitian ini lebih tinggi dibandingkan dengan penelitian Sahin et al. (2010) yaitu 0,20 $\pm 0,03 \mathrm{mg}$ $\mathrm{kg}^{-1}$. Tingginya kadar MDA tersebut dapat disebabkan oleh perbedaan kondisi lingkungan. Penelitian Sahin et al. (2010) dilaksanakan pada daerah beriklim sejuk, sedangkan penelitian ini dilaksanakan di daerah beriklim tropis yang cenderung memiliki suhu dan kelembaban yang tinggi. Maheswari et al. (2017) menyatakan semakin tinggi suhu lingkungan, maka kadar MDA akan semakin tinggi. MDA merupakan produk utama dari proses oksidasi polyunsaturated fatty acid (PUFA).

Tabel 4 Kadar MDA pada kuning telur puyuh

\begin{tabular}{lc}
\hline Perlakuan dalam air minum & MDA $\left(\mathrm{mg} \mathrm{kg}^{-1}\right)$ \\
\hline P0 (kontrol) & $3,15 \pm 0,81^{\mathrm{b}}$ \\
P1 $\left(3 \mathrm{ml} \mathrm{ekor}^{-1}\right.$ hari-1 $\left.^{-1}\right)$ & $1,90 \pm 0,83^{\mathrm{a}}$ \\
P2 $\left(6 \mathrm{ml} \mathrm{ekor}^{-1}\right.$ hari-1 $^{-1}$ & $2,01 \pm 0,35^{\mathrm{a}}$ \\
\hline Superskrip yang berbeda pada kolom yang sama menunjukkan \\
perbedaan yang nyata $(\mathrm{p}<0,05)$ pada uji lanjut kontras orthogonal
\end{tabular}

http://journal.ipb.ac.id/index.php/jurnalintp 
Tabel 5 pH dan Aw telur puyuh

\begin{tabular}{|c|c|c|c|}
\hline Variabel & PO & P1 & $\mathrm{P} 2$ \\
\hline \multicolumn{4}{|l|}{$\overline{\mathrm{pH}}$} \\
\hline Kuning telur & $6,24 \pm 0,01$ & $6,22 \pm 0,04$ & $6,22 \pm 0,05$ \\
\hline Putih & & & \\
\hline \multicolumn{4}{|l|}{$\begin{array}{l}\text { Water Activity } \\
\text { (Aw) }\end{array}$} \\
\hline Kuning telur & \multicolumn{2}{|c|}{$0,881 \pm 0,008^{b} 0,887 \pm 0,008^{b}$} & $0,867 \pm 0,009^{a}$ \\
\hline Putih telur & \multicolumn{2}{|c|}{$0,879 \pm 0,013^{b} 0,877 \pm 0,006^{b}$} & $0,859 \pm 0,009^{a}$ \\
\hline \multicolumn{4}{|c|}{$\begin{array}{l}\mathrm{P} 0 \text { (kontrol), } \mathrm{P} 1\left(3 \mathrm{ml} \text { jus daun afrika ekor }{ }^{-1} \text { hari }^{-1}\right), \mathrm{P} 2(6 \mathrm{ml} \text { jus daun } \\
\left.\text { afrika ekor }{ }^{-1} \text { hari }{ }^{-1}\right) \text {; Huruf yang berbeda pada kolom yang sama } \\
\text { menunjukkan perbedaan yang nyata }(\mathrm{p}<0.05) \text { pada uji lanjut kontra } \\
\text { orthogonal. }\end{array}$} \\
\hline
\end{tabular}

Antioksidan pada daun afrika berperan untuk mengubah radikal bebas menjadi ikatan-ikatan yang lebih aman (Nurfianti \& Tribudi 2016). Radikal bebas akan berikatan dengan antioksidan sehingga ikatannya lebih stabil dan tidak menimbulkan kerusakan. Produksi radikal bebas akibat cekaman panas dapat meningkatkan level MDA, menurunkan skor warna kuning telur, dan menurunkan nilai nutrien telur melalui peningkatan peroksidasi lipid pada kuning telur, sehingga berdampak pada penurunan kualitas telur. Level MDA yang tinggi juga berkorelasi dengan rendahnya nilai nutrien dan rasa telur (Fouad et al. 2016). Pada penelitian Ariqoh et al. (2019), diketahui pemberian daun pegagan dan limbah wortel mampu menurunkan kadar MDA dalam darah, hal ini karena pada daun pegagan mengandung senyawa aktif seperti saponin, polifenol, flavonoid, alkaloid yang mana pada daun afrika juga mengandung senyawa aktif tersebut.

\section{pH dan Water Activity (Aw) Telur Puyuh}

Hasil penelitian menunjukkan bahwa pemberian jus daun afrika tidak memberikan pengaruh pada $\mathrm{pH}$ kuning dan putih telur, namun berpengaruh pada nilai Aw kuning dan putih telur (Tabel 5). Suplementasi jus daun afrika diketahui tidak mempengaruhi nilai $\mathrm{pH}$ kuning dan putih telur. Menurut Teusan et al. (2009), putih telur memiliki pH berkisar 8,67-9,17 dan kuning telur memiliki pH berkisar 5,71-6,33. Sampel telur yang digunakan pada penelitian ini merupakan telur segar dan tidak melalui proses penyimpanan sehingga perubahan $\mathrm{pH}$ tidak terjadi.

Pemberian jus daun afrika dalam air minum memberikan perbedaan yang signifikan terhadap nilai Aw kuning dan putih telur. Perlakuan dengan pemberian jus daun afrika pada $6 \mathrm{ml} \mathrm{ekor}^{-1}$ hari-1 $^{-1}$ nyata menurunkan nilai Aw $(p<0,05)$ pada kuning dan putih telur puyuh. Penurunan nilai Aw dapat meningkatkan daya simpan telur dengan menurunnya pertumbuhan mikroba. Menurut Sholehah et al. (2015), mikroba umumnya dapat tumbuh pada Aw 0,6-0,99. Menurut Lestari et al. (2017), semakin tinggi kandungan antioksidan telur, maka dapat menekan terjadinya oksidasi dalam telur sehingga kualitas dan daya simpan telur meningkat. Sifat antimikroba pada daun afrika di duga dapat menekan pertumbuhan mikroba dalam telur sehingga dapat meningkatkan daya simpan. Mekanisme penurunan Aw pada kuning dan putih telur masih belum dapat dijelaskan terkait dengan adanya senaywa aktif pada jus daun afrika.

\section{SIMPULAN}

Pemberian jus daun afrika 3 dan 6 ml ekor-1 hari ${ }^{-1}$ pada puyuh Coturnix coturnix Japonica melalui air minum tidak mempengaruhi komposisi kimia kuning telur, namun mampu menurunkan kadar MDA. Penggunaan jus daun afrika sampai $6 \mathrm{ml}^{\text {ekor- }}{ }^{-1}$ hari $^{-1}$ mampu menurunkan nilai Aw telur puyuh.

\section{DAFTAR PUSTAKA}

[AOAC]. 1980. Official Method of Analysis. $12^{\text {th }}$ ed. Washington DC (US). Association of Official Analytical Chemist.

[AOAC]. 2012. Official Method of Analysis. 19th ed .Washington DC (US). Association of Official Analytical Chemist.

Ariqoh H, Prayoga S, Hermanto BS \& Hermana W.2019. Suplementasi jus daun pegagan dan limbah wortel terhadap produktivitas puyuh jantan (Coturnix coturnix Japonica). Jurnal Ilmu Nutrisi dan Teknologi Pakan. 17(2):54-58.

Atangwho IJ, Egbung GE, Ahmad M, Yam MF \& Asmawi MZ. 2013. Antioxidant versus antidiabetic properties of leaves from Vernonia amygdalina Del. growing in Malaysia. Food Chemistry. 141(4) : 3428-3434.

Dillasamola D \& Linda M. 2016. Uji Aktvitas antioksidan ekstrak etanol daun afrika selatan (Vernonia Amygdalina Del.) dengan menggunakan metode DPPH (1,1-diphenil-2-picryhydrazyl). Jurnal Akademi Farmasi Prayoga. 1(1):29-35.

Diplock AT, Symons MCR \& Rice-Evans CA. 1991. Tehniques in Free Radical Research. London (UK) : Elsevier Science.

Dudusola IO. 2010. Comparative evaluation of internal and external qualities of eggs from quail and guinea fowl. International Research Journal of Plant Science. 1(5):112-115.

Faradillah F, Mutia R \& Abdullah L. 2015. Subtitution of soybean meal with Indigofera zollingeriana top leaf meal on egg quality of Coturnix coturnix japonica. Media Peternakan. 28(3):192-197.

Ferazuma H, Marliyati SA \& Amalia L. 2011. Subtitusi tepung kepala ikan lele dumbo untuk meningkatkan kandungan kalsium crackers. Jurnal Gizi dan Pangan. 6(1):18-27.

Fouad AM, Chen W, Ruan D, Wang S, Xia WG \& Zheng CT. 2016. Impact of heat stress on meat, egg quality, immunity and fertility in poultry and nutritional factors that overcome these effects. Internation Journal of Poultry Science. 15(3):81-95.

Grigorova S, Nikolova M, Penkov D \& Gerzilov V. 2014. Egg yolk lipids change in japanese quail given Tribulus terrestris extract. Bulgarian Journal og Agricultural Science. 20(6) : 1472-1476.

Halimah H, Suci DM \& Wijayanti I. 2019. Studi potensi penggunaan daun mengkudu (Morinda citrifolia L) sebagai bahan antibakteri Eshericia coli dan Salmonella typhimurium. Jurnal Ilmu Peternakan Indonesia. 24(1):58-64.

Ho WY, Liang WS, Yeap SK, Beh BK, Yousr AH \& Alitheen NB. 2012. In vitro and in vivo antioxidant activity of Vernonia amygdalina water extract. African Journal of Biotechnology. 11(17):4090-4094.

Landung DC, Mahfudz LD \& Suthama N. 2013. Pengaruh penggunaan tepung buah jambu biji merah dalam ransum terhadap perkembangan usus halus dan pertumbuhan ayam broiler. Animal Agriculture Journal. 2(3): 73-84. 
Lestari LI, Widigdyo A, \& Ari NO. 2017. Pengaruh penambahan ekstak kayu secang Caesalpinia sappan dan minyak ikan lemuru sebagai aditif pakan terhadap daya simpan telur dan kolesterol telur puyuh. Jurnal Aves 11(2): 38-44.

Maheswari H, Sasmita AN, Farajallah A, Achmadi P \& Santosa K. 2017. Pengaruh suhu terhadap diferensial leukosit serta kadar malondialdehide (MDA) burung puyuh (Coturnix coturnix Japonica). Jurnal Bioma. 13(1) : 81-89.

Nurfianti A \& Tribudi YA. 2016. Kadar malondialdehid (MDA) dan kolesterol pada puyuh yang diberi pakan tambahan tepung pegagan (Centella asiatica). Jurnal Teknologi Pertanian. 17(3):187194.

Oboh,G.2006. Nutritive value and hemolytic properties (in vitro) of the leaves of Vernonia amygdalia of human erythrocyte. Nutrition and Health $18: 151-160$

Prelipcean AA \& Teusan V. 2012. Invertigations on the structure, chemical composition and caloricity of the quail eggs, deposited at the plateau phase of the laying period. Seria Zootehnie. 57:113-120.

Rukmiasih, Tjakradijadja AS, Sumiati \& Huminto H. 2009. Dampak penggunaan beluntas dalam upaya menurunkan kadar lemak daging terhadap produksi dan kadar lemak telur itik lokal. Jurnal Ilmu Pertanian Indonesia. 14(1) : 73-82.

Sahin K, Akdemir F, Orhan C, Tuzcu M, Hayirli A \& Sahin N. 2010. Effects of dietary resveratrol supplementation on egg production and antioxidant status. Poultry Sciences. 89:1190-1198.

Sholehah F, Thohari I \& Jaya F. 2015. Pengaruh penambahan sari lengkuas merah (Alpinia purpurata K. schum) dan lama simpan telur asin terhadap total mikroorganisme, aktivitas antioksidan, aktivitas air dan tekstur. Jurnal Ilmu dan Teknologi Hasil Ternak. 10(2):18-27.

Sinanoglou VI, Strati IF \& Meimaroglou SF. 2011. Lipid, fatty acid and caratenoid content of edible egg yolks from avian species : a comparative study. Food Chemistry. 124:971-977.

Suci DM, Zahera R, Sari M \& Hermana W. 2020. Penggunaan tepung kulit pisang dalam ransum terhadap kadar kolesterol, vitamin A dan profil asam lemak kuning telur ayam. Jurnal Ilmu Nutrisi dan Teknologi Pakan. 18(1): 11-18.

Sukmawati, Hadi H \& Aminah. 2017. Potensi senyawa flavonoid daun afrika (Vernonia amygdalina Del.) asal ternate sebagai antioksidan. Jurnal Asysyifa. 9(2):195-200.

Suprijatna E, Kismiati S \& Furi NR. 2008. Penampilan produksi dan kualitas telur pada puyuh yang memperoleh ransum protein rendah disuplementasi enzim komersial. Journal of The Indonesian Tropical Animal Agriculture. 33(1) : 66-71.

Teusan A, Teusan V \& Prelipcean AA. 2009. Research regarding some physical quality values of japanese quail eggs obtained at the middle of the laying stage. Zootehnie si Biotehnologii. 42(2):446451.

Tolik D, Polawska E, Charuta A, Nowaczeski S \& Cooper R. 2014. Characteristics of egg parts, chemical composition and nutritive value of japanese quail eggs. Folia Biologica. 62(4):287-292.

Tugiyanti E, Rosidi \& Anam AK. 2017. Pengaruh tepung daun sukun (Artocarpus artilis) terhadap produksi dan kualitas telur puyuh. Jurnal Agripet. 17(2):121-131.

Usunobun U \& Okolie NP. 2015. Phytochemical, trace and mineral composition of Vernonia amygdalia leaves. International journal of Biological and Pharmaceutical Research 6(5) : 393-399 